\title{
Üst Solunum Yolu Enfeksiyonlarında Hızlı Antijen Testleri ile Klinik Skorlama Sistemlerinin Karșılaștırılması
}

\author{
Comparison of Rapid Antigen Tests and Clinical Scoring Systems in Upper Respiratory Tract Infections
}

\author{
Ahmet KAYALI ${ }^{1}$, Umut PAYZA², Serkan BILLGİN ${ }^{3}$, Fatih Esad TOPAL ${ }^{4}$
}

\section{ÖZ}

Antibiyotiklerin Akılcı Kullanımı' güncel ve önemli konu başlıkları arasındadır. Hızlı antijen testlerinin (HAT) akılcı ilaç kullanımı için etkinliği kabul edilmiştir. Viral enfeksiyonun bakteriyelden ayrımı için çeșitli skorlama sistemleri geliștirilmiștir. Centor ve FeverPAIN klinik tanı testleri kullanılmaktadır. Çalışmamızın amacı antibiyotik kullanımını sınırlandırmaktır. Centor ve FeverPAIN testlerinin duyarlılığını arttırmak ve antibiyotiklerin reçete edilirken bakteriyal enfeksiyonların objektif bulgularına göre karar verilmesini sağlamaktır.

Boğaz ağrıs1, ateş, öksürük gibi üst solunum yolu enfeksiyonu bulguları olan hastalara, hekimleri tarafından, klinik tanı testleri ve hızlı antijen tanı testi performe edildi. Acil servise başvuran, 15 yaş üzeri hastalar çalışmaya dahil edildi. HAT'i açık bir şekilde sonuçlanan 232 hasta çalışmaya dahil edildi.

Centor ve FeverPAIN klinik tanı testleri, hızlı antijen testinin sonuçlarına göre karşılaştırdığımızda her iki klinik testinde antibiyotiklerin kullanımına karar vermede değerli olduğunu hesaplandı. Ayrıca, çalışmamızda Centor ve feverPAIN testlerinin parametrelerini analiz ettik. $\mathrm{Bu}$ parametrelerden istatistiki anlamlılığ olan yaş, tonsiller eksüda, orofarengeal inflamasyon ve öksürük için elde edilen verileri değerlendirdik. Tosiller eksuda görünümü orta-kuvvetli, orofarengeal inflamasyon orta-zayif anlamlı, 15-45 yaş ve öksürüğ̈̈n olmaması zayıf anlamliyd.

Kültür örneklemeleri ve hızlı antijen tanı testlerinin yapılmadığı sağlık merkezlerinde kullanılacak Centor, feverpain ve modifiye skorlar yerine, yalnızca, tanısal değerliliği yüksek tonsiller eksüda ve orofarengeal inflamasyonun kullanılmasını öneriyoruz.

Anahtar Kelimeler: Hızlı Antijen Tanı Testi, Centor testi, FeverPAIN testi

\begin{abstract}
Rational antibiotic use' is therefore an ongoing and important issue. The rapid antigen detection test (RADT) is regarded as effective. Centor and FeverPAIN scoring systems have therefore been developed to differentiate viral from bacterial infections. The objective of this study is to restrict antibiotic use. Increasing the sensitivity of the Centor and FeverPAIN scores will enable decisions based on objective bacterial findings to be taken when prescribing antibiotics.
\end{abstract}

Physicians performed clinical diagnostic tests and the RADT on patients with upper respiratory tract infection (URTI) findings. Patients aged over 15 years were included in the study. 232 patients with unambiguous RADTs were finally enrolled.

Comparison of Centor and FeverPAIN clinical prediction scores frequently employed in the clinical decision process with RADT results revealed that both clinical prediction scores were valuable in the decision to employ antibiotics. Also, this study analyzed Centor and FeverPAIN clinical prediction parameters. We evaluated the data obtained for those parameters identified as statistically significant - age, tonsillar exudate, oropharyngeal inflammation, and cough.

We therefore recommend that tonsillar exudate and oropharyngeal inflammation, with their high diagnostic values, should be used, rather than Centor, FeverPAIN and modified scoring systems, in health centers in which culture sampling and RADTs are not available.

Keywords: Rapid Antigen Detection Test, Centor Score, FeverPAIN Score.

${ }^{1}$ Uzm. Dr., Ahmet KAYALI, Acil Tıp, İzmir Katip Çelebi Üniversitesi Atatürk EAH, ahmetkayali@hotmail.com, ORCID:0000-0003-25570600

${ }^{2}$ Dr.Öğr. Üyesi, Umut PAYZA, Acil Tıp, İzmir Katip Çelebi Üniversitesi Atatürk EAH, umutpayza@hotmail.com, ORCID:0000-0002-52971066

${ }^{3}$ Dr. Öğr. Üyesi, Serkan BILLGIN, Acil Tıp, İzmir Katip Çelebi Üniversitesi Atatürk EAH, serk42@hotmail.com, ORCID: 0000-0001-93458878

${ }^{4}$ Prof. Dr., Fatih E. TOPAL, Acil Tıp, Katip Çelebi Üniversitesi Atatürk EAH, fatihetopal_18@hotmail.com,ORCID:0000-0002-9941-4224

İletişim / Corresponding Author: $\quad$ Dr. Öğr. Üyesi Umut PAYZA

Geliş Tarihi / Received: $\quad 26.01 .2021$

e-posta/e-mail:

umutpayza@hotmail.com

Kabul Tarihi/Accepted: $\quad 30.07 .2021$ 


\section{GíRiş}

Özellikle son yıllarda bakterilerin antibiyotiklere karşı geliştirdikleri direnç tüm dünya için önemli bir sağlık sorunu haline gelmiştir. Dolayısıyla, direnç gelişiminin önlenmesi de tüm ülkelerin temel sağlık politikalarının öncelikli hedefleri arasında yer almaktadır. Her yıl, yalnızca Amerika'da antibiyotik direnci nedeniyle milyonlarca vaka bildirilmektedir ${ }^{1}$. $\mathrm{Bu}$ nedenle hem ulusal hem de uluslararası sağlık kuruluşları için 'Bakteriyel Ajanlara Karşı Tedavi' güncel ve önemli bir konu başlığıdır ${ }^{2}$.

Üst solunum yolu enfeksiyonlarında (ÜSYE) etken yetişkinlerde çoğunlukla viral patojenlerdir. Yalnızca, $\% 5$ ila \%15'i bakteriyel bir nedene bağlıdır. Yine, bakteriyel komplikasyonlar \%1'in altında görülmektedir. Buna rağmen üst solunum yolu hastalığı düşündüren semptomları olan hastaların \%56-\%78'ine antibiyotik reçete edilmektedir ${ }^{3}$.

Bu noktada en önemli basamak bakteriyel etkenlerin viral etkenlerden ayrımıdır. $\mathrm{Bu}$ ayrımın yapılabilmesi içinde farklı tanı yöntemleri mevcuttur. 'Altın Standart' tanı yöntemi kültür çalışmalarıdır. Ancak, özellikle aile hekimliği gibi temel sağlık birimlerinde ve acil servislerde başvuru sayılarının fazla, sürenin sinırlı ve maliyetinin yüksek olması nedeniyle tercih edilen bir tanı yöntemi değildir. Ayrıca, kültür sonuçlarının günler içinde sonuçlanması nedeniyle kullanımları kısıtlıdır. Diğer güncel ve uluslararası kabul edilen yöntem de hızlı antijen testlerdir. Yapılan çalışmalarda hızlı antijen testlerinin (HAT) tanısal etkinliği \%78-95 olarak hesaplanmış ve etkinliği kabul edilmiştir. Bu nedenle, Amerika Enfeksiyon Hastalıkları Derneği'ne ve Avrupa Klinik Mikrobiyoloji ve Enfeksiyon Hastalıkları Derneği, hızlı antijen testlerini, klinik uygulama kılavuzlarına dâhil etmiştir 4. Ancak, hızlı antijen testlerinin sonuçlanma süresi de 15 ila 30 dakika arasındadır. Ayrıca, maliyetli ve sürekli tedarik edilmesi gerekli testlerdir. Kültür ve antijen testlerinin zaman ve maliyet dezavantajları nedeniyle, klinik skorlama sistemleri geliştirilmiştir. Centor ve FeverPAIN testleri basit klinik bulgularla bakteriyel enfeksiyonların tanınmasında uluslararası kabul görmüş yöntemler arasında yer almaktadir ${ }^{4-6}$.

$\mathrm{Bu}$ çalışmada, A grubu Streptekokların tanı metotları arasında yer alan hizlı antijen testleri ile klinik tanı testlerini karşılaştırdık. Klinik tanı testlerinin tanıdaki etkinliğini ve bakteriyel patojenlerin belirlenmesindeki rolünü analiz ettik.

\section{MATERYAL VE METOT}

Çalışmamız 1 Ocak - 31 Mart 2019 tarihleri arasında prospektif olarak çalışıldı. Boğaz ağrısı, ateş, öksürük gibi üst solunum yolu enfeksiyonu bulguları olan hastalara, hekimleri tarafından, klinik tanı testleri ve hızlı antijen tanı testi uygulandi. Elde edilen veriler analiz edildi.

Acil servise başvuran, acil servisimiz 14 yaş ve altı hasta başvurusu olmaması ve Centor tanı testi esas alınarak yaş sınırı 15 kabul edildi. Vital bulguları stabil olmayan, ikincil patojenler tarafindan enfeksiyon odağ belirlenen, romatizmal ateş veya kalp kapak hastalığı olan ve immünosüprese hastalar çalışmaya alınmadı. Tekrarlayan veya kronik farenjiti olan hastalar (semptomlar >7gün), boğaz ağrıları akut enfeksiyöz farenjit dışında bir nedene bağlı olduğu belirlenen hastalar çalışma dişı bırakıldı. Malignite tanisı olan ve/veya tedavi alan hastalarda çalışmaya dahil edilmedi.

Çalışmaya 301 hasta katıldı. HAT testi kesin sonuç veren 131'i kadın, ve 101'i erkek 232 hasta çalışmaya dahil edildi. Elde edilen veriler hastalar için hazırlanan formlara yazıldı. HAT, FeverPAIN ve Centor testleri çalışmaya katılan hekimler tarafından uyguland1. 


\section{İstatisitik ve Veri Analizi}

Verilerin istatistiksel analizi IBM SPSS Statistics Version 22 paket programında yapıld1. Gruplar aras1 kategorik verilerin karşılaştırılmasında Pearson Ki-Kare ve Fisher's Exact testi, sürekli verilerin normal dağılımda olmaması nedeniyle gruplar arası karşılaştırmalarda Mann Whitney U istatistiksel analiz kullanıldı (Kolmogorov Smirnov ve Shapiro Wilks ; $\mathrm{p}<0,05)$. Centar ve Feverpain parametrelerinin her biri için ROC analizi yapıldı.

\section{Klink Tanı Testleri}

Centor ve FeverPAIN testleri klinik bulgular ile bakteriyal/viral etkenlerin ayrımını sağlayan klinik bulgulara dayalı testlerdir. 1980'li yıllardan bu yana, özellikle tanı testleri uygulanamayan sağlık merkezlerinde kullanılmaktadırlar ${ }^{4-6}$. Ancak, ülkemizde kullanımı sınırlıdır.

Centor testi yaş, ağrılı lenfadenopati, tonsiller eksuda, ateş yüksekliği ve öksürük parametrelerinden oluşmaktadır. Yaş 314/15-45/>45 olarak ayrılmış ve $-1 / 0 / 1$ olarak puanlanmıştır. Diğer parametreler var/yok olarak cevaplanılmış ve $0 / 1$ olarak puanlandırılmıştır. Centor skoru 0 ile 5 arasında değişmekte ve yüksek puanlar bakteriyal enfeksiyon riskininde arttığını işaret etmektedir.

ÜSYE yönetimi-NICE kılavuzda, FeverPAIN, Centor'a alternatif olarak kullanılmaktadır. Tonsiller üzerinde püy varlığı, ilk 3 gün içerisinde başvuru, tonsiller inflamasyon bulguları, öksürük ve nezle semptomlarının varlığ sorgulanır. Her parametreler var/yok olarak cevaplanılmış ve $0 / 1$ olarak puanlandırılmıştır. Skor 0 ile 5 arasında değişmekte ve yüksek puanlar bakteriyel enfeksiyon riskininde arttığı kabul edilmektedir.

Skorlama için; Amerika Bulaşıcı Hastalıklar Derneği ve Amerikan Doktorlar Koleji sadece 4 veya 5 puan için ampirik tedavi önermektedir.

- 1, 0 veya 1 puan; Antibiyotik veya boğaz kültürü gerekmez (strep. Enfeksiyon riski $<\%$ 10)

- 2 veya 3 puan; Boğaz kültürü almalı ve kültür pozitifse antibiyotikle tedavi edilmelidir (strep. Enfeksiyon riski 3 kriter ise\% 32, 2 ise \% 15)

- 4 veya 5 puan; Hizlı strep testi ve / veya kültürü düşünün. (Strep. Enfeksiyon riski\% 56)

\section{Araştırmanın Etik Yönü}

Çalıșma izni XXX Üniversitesi Etik Kurulu Başkanlığından 26.09.2019/398 tarih/no'lu etik kurul onayı ve kurum izni alınmıştır. Çalışmaya katılan tüm gönüllülerden yüz yüze görüşme yapılarak onam alındı. Çalışmanın tüm aşamalarında Helsinki Deklarasyonuna uyuldu.

\section{Araştırmanın Kısıtlılıkları}

Çalışmamızda, acil servislerde ve birinci basamak sağlık kuruluşlarında kültür testlerine ulaşma imkânının kısıtlılıklar arasında yer almaktadır. Çalışma randomize ancak tek merkezli yapılmıştır. Çok merkezli ve daha çok vaka sayısına ulaşılan çalışmalara ihtiyaç duyulmaktadır.

Her ne kadar hızlı antijen testlerinin kolerasyonu için kültür çalışmaları yapılmaması bir sınırlılık olarak görünse de uluslararası kılavuzlar hızlı antijen testlerinin güvenilir olduğunu kabul edilmiştir ${ }^{4-6}$.

\section{BULGULAR VE TARTIŞMA}

Çalışmaya 131 kadın, 101 erkek toplam 232 dahil edildi. Kadınların yaş ortalaması $34 \pm 0,5$, ve erkeklerin $35 \pm 1,7$ olarak hesaplandi.
Yaşlar arasında anlamlı istatistiksel fark görülmedi. Acil servise başvuran hastalarda Centor ve FeverPAIN klinik testlerinin analizi yapıldı. Test sonuçlarına ait sonuçlar Tablo 1'de özetlendi. 
Tablo 1. Centor ve Feverpain Testlerine Ait Kategorik Değişkenlerin Dağılımı ve Hızlı Antijen Test Sonuçları

\begin{tabular}{|c|c|c|c|}
\hline Kategori & Değişken & $\mathbf{n}$ & $\%$ \\
\hline \multirow[t]{3}{*}{$\begin{array}{l}\text { Hzzl Antijen } \\
\text { Testi Sonucu }\end{array}$} & Pozitif & 51 & 22,3 \\
\hline & Negatif & 178 & 77,7 \\
\hline & $15-45$ yaş & 158 & 75,2 \\
\hline Yaş & 45 yaş üstü & 52 & 24,8 \\
\hline \multirow{2}{*}{$\begin{array}{l}\text { Ağrilı Anterior } \\
\text { Servikal } \\
\text { Lenfadenopati }\end{array}$} & Var & 26 & 11,3 \\
\hline & Yok & 204 & 88,7 \\
\hline \multirow{2}{*}{$\begin{array}{l}\text { Tonsiller } \\
\text { Üzzerinde Eksüda }\end{array}$} & Var & 68 & 29,3 \\
\hline & Yok & 164 & 70,7 \\
\hline \multirow{2}{*}{ Ateş Yüksekliği } & Var & 91 & 39,4 \\
\hline & Yok & 140 & 60,6 \\
\hline \multirow{2}{*}{ Öksürük } & Yok & 65 & 27,9 \\
\hline & Var & 168 & 72,1 \\
\hline \multirow{2}{*}{$\begin{array}{l}\text { Ateş Yüksekliği } \\
\text { (Son } 24 \text { Saatte) }\end{array}$} & Var & 108 & 46,8 \\
\hline & Yok & 123 & 53,2 \\
\hline \multirow{2}{*}{$\begin{array}{l}\text { Tonsiller } \\
\text { Üzerinde Eksüda }\end{array}$} & Var & 68 & 29,3 \\
\hline & Yok & 164 & 70,7 \\
\hline \multirow{2}{*}{$\begin{array}{l}\text { Semptom Başlangıcı } \\
3 \text { Günü Geçmiş }\end{array}$} & Yok & 110 & 47,2 \\
\hline & Var & 123 & 52,8 \\
\hline \multirow{2}{*}{$\begin{array}{l}\text { Orofarenk } \\
\text { Bakisinda } \\
\text { İnflamasyon }\end{array}$} & Var & 196 & 84,5 \\
\hline & Yok & 36 & 15,5 \\
\hline \multirow{2}{*}{ Üsye Semptomları } & Yok & 5 & 2,2 \\
\hline & Var & 226 & 97,8 \\
\hline
\end{tabular}

Hizlı antijen testi sonucu ile Centor skorlaması parametreleri uyumu için yapılan Kappa analizi sonuçları incelendi. Hızlı antijen testi ile yaş arasında negatif yönde ve zayıf derecede, ağrılı anterior servikal lenfadenopati ve öksürük parametreleri arasında pozitif yönde ve zayıf derecede, tonsiller üzerinde eksüda parametresi arasında pozitif yönde, istatistiksel olarak anlamlı bulundu $(\mathrm{p}<0,05)$. Ateş yüksekliği ile hızlı antijen testi sonuçları arasında istatistiksel olarak anlamlı uyum bulunmadı (Tablo.2).
Tablo 2. Hızlı Antijen Testi Sonucu İle Centor Testi Analizi

\begin{tabular}{lcccc}
\hline Kategorik Değişken & & $\begin{array}{c}\text { Pozitif } \\
\text { \% }\end{array}$ & $\begin{array}{c}\text { Negatif } \\
\text { \% }\end{array}$ & p \\
\hline \multirow{2}{*}{ Yaş } & $15-45$ & 90 & 71,5 & \\
Ağrnlı Anterior & $>45$ & 10 & 28,5 & $\mathbf{0 , 0 1 5}$ \\
Servikal Lenfadenopati & Var & 3,5 & 6,9 & \\
& Yok & 6,5 & 93,1 & $\mathbf{0 , 0 0 1}$ \\
Tonsiller & Var & 0,4 & 14,2 & \\
Üzerinde Eksüda & Yok & 9,6 & 85,8 & $\mathbf{0 , 0 0 0}$ \\
Ateş Yüksekliği & Var & 1 & 36,4 & \\
& Yok & 9 & 63,6 & 0,060 \\
Öksürük & Yok & 3,1 & 22,6 & \\
& Var & 6,9 & 77,4 & $\mathbf{0 , 0 0 4}$ \\
\hline
\end{tabular}

Hızlı antijen testi sonucu ile FeverPAİN skorlaması parametreleri uyumu için yapılan Kappa analizi sonuçları analiz edildi. Tonsiller üzerinde püy için orta-kuvvetli derecede ve orofarenks bakisında inflamasyon için pozitif yönde, zayıf derecede istatistiksel olarak anlamlı bulundu $(p<0,05)$. ÜSYE semptomları, son 24 saatte ateş yüksekliği ve semptom başlangıcının 3 günü geçmiş olması ile hızlı antijen testi sonuçları arasında istatistiksel olarak anlamlı sonuç bulunmadı (Tablo.3).

Tablo 3. Hızlı Antijen Testi Sonucu İle Feverpain Testi Analizi

\begin{tabular}{lcccc}
\hline Kategorik Değişken & & $\begin{array}{r}\text { Pozitif } \\
\text { \% }\end{array}$ & $\begin{array}{r}\text { Negatif } \\
\text { \% }\end{array}$ & p \\
\hline $\begin{array}{l}\text { Ateș } \\
\text { (Son 24 saatte) }\end{array}$ & Var & 54,9 & 43,4 & \\
$\begin{array}{l}\text { Tonsiller } \\
\text { üzerinde püy }\end{array}$ & Var & 80,4 & 14,2 & \\
& Yok & 19,6 & 85,8 & $\mathbf{0 , 0 0 1}$ \\
Semptom > 3 günü & Yok & 56,9 & 43,5 & \\
& Var & 43,1 & 56,5 & $\mathbf{0 , 0 0 0}$ \\
Orofarenk & Var & 100,0 & 80,1 & \\
inflama görünüm & Yok & 0,0 & 19,9 & 0,060 \\
Üsye semptomları & Yok & 3,9 & 1,1 & \\
\hline
\end{tabular}

Hizlı antijen testi sonucu tahmininde Centor ve FeverPAIN klinik tanı testleri parametrelerinin tanısal değerliliğinin belirlenmesi için ROC analizleri yapıld1. Bu parametrelerden; yaş, öksürük, tonsiller üzerinde eksüda/püy ve orofarenk bakısında inflamasyon için hesaplanan AUC değerleri 
istatistiksel olarak anlamlı bulundu. Diğer parametreler ise istatistiksel fark görülmedi. Tonsiller üzerinde eksüda-püy, orta-kuvvetli anlamlı iken; orofarenks bakısında inflamasyon orta-zayıf anlamlı; ağrılı anterior servikal lenfadenopati, 45 yaş üstü olmaması ve öksürük olmaması zayıf anlamlı bulundu (Tablo.4).

Tablo 4. Bakteriyal Enfeksiyon İle Centor And Feverpaın Parametreleri İçin Yapılan ROC Analizi

\begin{tabular}{|c|c|c|c|c|}
\hline Kategorik Değişken & Sens & Specif & AUC & $\mathbf{p}$ \\
\hline 45 yaş ve üstü & 90 & 28,48 & 0,572 & 0,094 \\
\hline cLAP & 23,53 & 93,1 & 0,583 & 0,085 \\
\hline Tonsiller eksüda & 80,39 & 85,8 & 0,831 & $<0,0001$ \\
\hline Ateş & 50,98 & 63,64 & 0,573 & 0,112 \\
\hline Öksürük & 43,14 & 77,4 & 0,583 & 0,085 \\
\hline Ateş (Son 24 saatte) & 54,9 & 56,57 & 0,557 & 0,210 \\
\hline Semptom >3 günü & 56,86 & 56,5 & 0,567 & 0,143 \\
\hline $\begin{array}{l}\text { Orofarenks } \\
\text { inflama görünüm }\end{array}$ & 100 & 19,89 & 0,599 & $<0,0001$ \\
\hline ÜSYE semptomları & 3,92 & 98,86 & 0,514 & 0,766 \\
\hline
\end{tabular}

Klinik karar vermede kullanılan Centor ve FeverPAIN klinik tanı testleri ile hızlı antijen testinin sonuçları karşılaştırıldığında her iki klinik tan 1 testinin de bakteriyel enfeksiyonlar ile viral enfeksiyonları başarılı şekilde ayırabildiğini gördük. Centor için sensitivite \%94, spesifisite \%53 idi. FeverPAIN için sensitivite \%64, spesifisite $\% 72$ olarak hesaplandi.

Amerika Birleşik Devletleri, dirençli bakteriler nedeniyle y1lda 2 milyon vaka ve 23 bin ölüm bildirmiştir ${ }^{1}$. Avrupa Birliği ülkelerinden de antibiyotik dirençli etkenler nedeniyle ölümlerde büyük artış gözlenmektedir ${ }^{5}$. Hizla büyüyen bu tehdit nedeniyle bakteriyel ile viral enfeksiyonların birbirinden ayrılması gerektiği tüm uluslararası bildirilerde altı çizilerek vurgulanmaktadir. Patojen etkenin belirlenmesi sağlanarak antibiyotik tüketiminin ve dolasıyla oluşturacakları direncin önüne geçilmesi temel hedeftir. Amerika Hastalık Kontrol ve Önleme Merkezleri $(C D C)$ ve Amerikan Doktorlar Koleji/Amerikan İç Hastalıkları Derneği $(A C P-A S I M)$ kültür ve test kitlerinin zaman ve maliyet dezavantajları nedeniyle, özellikle de birinci basamak sağlık merkezlerinde, klinik tanı testlerinin kullanılması gerekliliğini raporlamıştır ${ }^{6}$.

Ülkemizde, birinci basamak sağl1k hizmetleri merkezleri ve acil servislere, yılın her döneminde, üst solunum yolu semptomları ile çok sayıda hasta başvurmaktadır. 'Dünya Sağlık Örgütü Antimikrobiyal Tüketim Ağı Verileri 2017 y1li raporunda antibiyotiklerin en sik bu nitelikteki tıbbi birimlerde reçete edildiği vurgulanmaktadır. Aynı raporda antibiyotik kullanması gereken hasta ortalamasinın $\% 5$ 'i geçmemesine rağmen, hastaların \%75-80'ine, herhangi bir test ya da klinik tanı testi uygulanmadan antibiyotik reçete edildiği bildirilmiştir. Raporda, ülkemiz, antibiyotik tüketiminde yıllık 1000 kişi başına 40.2 gramla iktisadi İşbirliği ve Gelişme Teşkilatı ülkeleri (OECD) arasında birinci sirada yer almaktadır $^{7}$.

Altın standart tanı yöntemi kültür çalışmalarıdır. Ancak, birinci basamak sağlık hizmetleri ve acil servislerde hizlı antijen testleri ve kültürlerin kullanımı oldukça kısıtlıdır. $\mathrm{Bu}$ testler, sonuçlarının elde edileceği sürenin uzun olması ve sağlık harcamalarını arttırması nedeniyle, günlük pratiğimizde de uygulanmamaktadır. Buna rağmen bakteriyel ve viral enfeksiyonların ayrımı yapılmadan üst solunum yolu enfeksiyonu semptomları bulunan tüm hastalara, özellikle antibiyotikler, reçete edilmektedir.

CDC ve ACP-ASIM tarafindan üst üste yayınlanan raporlardan sonra, birinci basamak sağlık kuruluşlarında ve acil servislerde klinik tanı testlerinin kullanımı yeniden gündeme gelmiştir. $\mathrm{Bu}$ raporda, CDC ve ACP-ASIM, Centor veya FeverPAIN testlerinin kullanımının gerekliliği vurgulanmaktadır ve bu testlerin bakteriyal ve viral etkenleri birbirinden ayırmada yeterli olduğunu raporlamıştır ${ }^{6}$.

Monique Doddat ve ark çalışmasında Group A DNA probe test (GADNA) ile hizlı antijen tanı testini karşılaştırmıştır. GADNA ile karşılaştırıldığında hızlı antijen testlerinin kullanılması duyarlılığı düşürse de güvenilir 
sonuçlar verdiğini yazmıştır ${ }^{8}$. Ruiz-Aragón $\mathrm{J}$ ve ark ise yaptıkları meta-analizde klinik tanı testleri ile hizlı antijen testlerini karşılaştırmıştır. Klinik tanı testlerinin de HAT kadar etkin kullanılabileceği sonucuna varmış ve bu testlerin duyarlılığının \%65,6 ila \%96,4, özgüllüğünün ise \%68,7 - \%99,3 arasında olduğu bildirmiştir ${ }^{9}$.

S. Balasubramanıan ve ark Centor test sonuçlarını boğaz swap kültürleri ile karşılaştırmıştır. $\mathrm{Bu}$ çalışmanın sonucunda testin duyarlılığının \%89,7, özgüllüğünün ise \%98,4 olduğu hesaplanmıştır ${ }^{10}$. Paul Little benzer nitelikteki çalışmasında da klinik tanı testlerinin kullanımının, çalışmamızda elde edilen sonuca benzer şekilde, güvenli ve yeterli olduğunu, antibiyotik kullanımını azaltmasının muhtemel olduğunu ve çocuk hasta gruplarında dahi güvenle kullanılabileceğini yazmıştır ${ }^{11}$.

Çalışmamızın bir diğer amacı da antibiyotiklerin uygun endikasyonları dişında kullanımını sınırlamak ve reçete edilmesi için objektif bulgulara göre karar verilmesini sağlamak idi. Hızlı antijen testi ve klinik tanı testlerini ROC analizi ile karşılaştırdığımızda (Tablo 4), tonsiller eksüda ve orofarengeal inflamasyonun bakteriyal enfeksiyonlar ile anlamlı ilişskisi olduğunu gördük. Tonsiller eksüda ve orofarengeal inflamasyonun karar vermedeki etkinliğini HAT ile karşılaştırdığımızda güvenilirliğinin yüksek ve bakteriyal etkenlerle viral etkenleri ayırmada etkin olduğunu gözlemledik. Bununla beraber, tanı testlerine ait diğer değişkenlerin ise ayırıcı tanıda anlamlı olmadığını hesapladık. Benzer şekilde, $\mathrm{M}$. Bruce Edmonson ve ark çalışmasında bağımsız testler için mevcut pediatrik uygulama kurallarını karşılayacak kadar hassas kabul edilebileceğini belirtmiştir ve yalnızca tonsiller eksüdası olan ve öksürüğü olmayan çocuklar için bakteriyel etkenlerin ön planda olduğunu belirtmiştir ${ }^{12}$. Singer ve ark çalışmasında çalışma sonuçlarına bakarak klinik tanı testlerinden 'Ateş' değerinin tanı kriterlerinden çıkarılması gerektiğini belirtmiştir ${ }^{13}$.

Bizde çalışmamızda ateşin varlığ veya yokluğunun enfeksiyon etkeninin belirlenmesinde anlamlı olmadığı gördük. Öksürük, yaş, semptom süresi lenfadenopati ve ÜSYE semptomlarının bakteriyel etkenleri işaret etmediğini, ayırıcı tanıda objektif bir bulgu olarak kullanılmayacağını gözlemledik.

Çalışmamızın sonuçlarına baktığımızda uluslararası çalışmalarla benzer nitelikte sonuçlara ulaştığımızı görmekteyiz. Yalnızca tonsiller eksüda ve farangeal inflamasyonun varlığ 1 hizlı antijen testleri ile kolerasyon göstermekteydi ve bakteriyel etkenlerin belirlenebilmesi için yeterli duyarlılığa sahip olduğunu hesapladık. Bununla beraber yaş, ağrılı lenf nodu, ateş, öksürük semptomların süresi ve üst solunum yolu enfeksiyonuna ait bulguların enfeksiyenöz etkeni ayırmada yeterli duyarlılığı olmadığını gözlemledik.

Klinik tanı testlerinin uygulanmasının kısa süreli olması, maliyetinin bulunmaması ve güvenilir sonuçlara sahip olmasının tanı ve tedavi sürecinde önemli olduğunu inanıyoruz. Hastalarda, yalnızca, tonsiller ve farangeal inflamasyon bulgularına bakılarak bile etken tahmininde bulunulabileceğini, bu sayede özellikle antibiyotiklerin uygunsuz reçete edilmesinin sinırlanabileceğini düşünüyoruz.

\section{SONUÇ VE ÖNERILLER}

Antibiyotik direnci nedeniyle mortalite ve morbidite oranları sürekli artmaktadır. Ölümlerin engellenmesi için antibiyotik kullanımı sınırlandırılmalıdır. $\mathrm{Bu}$ nedenle, etkenin belirlenmesinde, kültür örneklemeleri ve hızlı antijen tanı testlerinin yapılamadığ sağlık merkezlerinde tanısal değerliliği yüksek tonsiller eksüda ve orofarengeal inflamasyonun kullanılmasını öneriyoruz. 
1. Evan Martensand Arnold, L. (2017). "The Antibiotic Resistance Crisis, with a Focus on the United States". The Journal of Antibiotics, 70, 520-526

2. Goossens, H, Ferech, M, VanderStichele, R. et al. (2005) "Outpatient Antibiotic Use in Europe and Association with Resistance: A Cross-National Data Base Study". Lancet, 365, 579-587.

3. Schroeck, J.L, Ruth, C.A, Sellick, J.A, et al. (2015). "Factors Associated with Antibioticmis Use in Outpatien Ttreatment for Upper Respiratory Tractinfections". Antimicrob Agents Chemother, 59, 3848-3852.

4. Shulman, S.T, Bisno, A.L, Clegg, H.W. et al. (2012). "Clinical Practice Guideline for The Diagnosis and Management of Group A Streptococcal Pharyngitis: 2012 update by the Infectious Diseases Society of America". Clin Infect Dis, 55 (10), 1279-1282

5. Antimicrobial consumption in Europe. (2012). Surveillance of. Stockholm: European Centre for Disease Prevention and Control. http://ecdc.europa.eu/en/eaad/antibioticsget-infor med/antibiotics-resistance/data-reports/ (Erişim tarihi: 15.12. 2020).

6. Snow, V, Mottur-Pilson, C, Cooper, R.J. et al. (2001). "American Academy of FamilyPhysicians; American College of Physicians-AmericanSociety of InternalMedicine; Centers for Disease Control. Principles of Appropriate Antibiotic Use for Acut Epharyngitis in Adults". AnnIntern Med, 134 (6), 506-508.

7. World Health Organization (WHO) Antimicrobial Consumption Network Data in 2017 report http://www.euro.who.int/data/assets.pdf_file/0007/337984/510 20-who-amc-report (Erişim tarihi: 15.12.2020).

8. Dodd, M, Adolphe, A, Parada, A. et al. (2018). "Clinical Impact of a Rapid Streptococcal Antigen Test on Antibiotic Use in Adult Patients". Diagnostic Microbiology and Infectious Disease, 91 (4), 339-344.

9. Ruiz-Aragón, J, RodríguezLópez, R. and MolinaLinde, J.M "Evaluation of Rapid Methods for Detecting Streptococcus Pyogenes". Systematic Review and Meta-Analysis. An Pediatr (Barc) 72, 391-402

10. Balasubramanian, S, Sumanth, A. and Dhanalakshmı, K. et al (2018). Rapid Antigen Diagnostic Testing For The Diagnosis of Group A Beta-Haemolytic Streptococci Pharyngitis". The National Medical Journal of IndiaVol. 31, 1, 2.

11. Paul Little, F.D, Richard, H, Michael, M. et al. (2013). "On Behalf of the PRISM Investigators Clinical Score and Rapid Antigen Detection Test To Guide Antibiotic Use for Sorethroats: Randomisedcontrolledtrial of PRISM". BMJ, 2, $347 f 5806$.

12. Bruce, M, Edmonson, K. and Farwell R. (2015). Relationship Betweenthe Clinical Likelihood of Group A Streptococcal Pharyngitis and the Sensitivity of a Rapid Antigen Detection Test in a Pediatric Practice; Pediatrics, 115 (2), 280-285.

13. Singer, M. (2016). "The Third International Consensus Definitions for Sepsis and Septic Shock". JAMA, 3, 801. 